\section{Bacteriocins in Erwinia aroideae with Tail Like Structure of Bacteriophages}

\author{
Shuwsei KamimiYa, Kazuo IzAKI \\ and Hajime TAKAHASHI
}

\author{
The Department of Agricultural Chemistry \\ Faculty of Agriculture, Tohoku University, \\ Sendai 980
}

Received December 13, 1976

The bacteriocins are bactericidal substances, protein in nature, which are synthesized by certain strains of bacteria and are active against some other strains of the same or closely related species of bacteria. The production of bacteriocins appears to be a widespread phenomenon. In most cases, each family of bacteriocins consists of many different types with the variation in the detailed activity spectra. Although many reports on bacteriocin have been appeared, only a few reports on bacteriocin from Erwinia species have been published until now. Hamon and Péron found that some strains belonging to genus Erwinia produced bacteriocins, ${ }^{1)}$ which they called carotovoricin. Endo, Tsuyama and Nakatani suggested that the antibacterial agents produced by Erwinia carotovora are bacteriocins characterized as a large molecular protein. ${ }^{2}$ ) Carotovoricin, however, have not been purified homogeneously and characterized, so far.

It has been reported from this laboratory that the pectolytic enzyme formation of Enwinia aroideae (AMS 6082) is markedly stimulated when nalidixic acid, mitomycin $\mathrm{C}$ or bleomycin, which are all known as inhibitors of DNA synthesis, is added to a culture medium. It has also been suggested that the pectolytic enzyme formation is accompanied with the induction of bacteriophage-like particles. ${ }^{3)}$ In previous paper, we have shown that the pectolytic enzyme induced by nalidixic acid was different from the enzyme formed under normal growth conditions, and suggested that the phage-like particles may be bacteriocins. ${ }^{4)}$

To investigate whether or not phage-like particles induced by nalidixic acid have bacteriocin activity, we tested susceptibility to these particles of various strains of Erwinia species as indicator strains. As shown in Table I, the cell-free culture fluid from Erwinia aroideae (AMS 6082) induced by nalidixic acid showed the bacteriocin activity against both Erwinia carotovora-2 and Erwinia aroideae-645Ar. This bacteriocin activity was also induced by mitomycin $\mathrm{C}$ or ultraviolet light irradiation, while it could not be detected in the culture fluid of normal growth. The bacteriocin
TABle I. Susceptibilities of Various

Strains of Genus Erwinia to

Bacteriocin-like Particles Induced BY NALIDIXIC ACID

An overnight culture of each strain in nutrient broth (about $10^{7}$ bacteria) was seeded onto a $10-\mathrm{ml}$ base layer of nutrient agar. The plate was incubated at $30^{\circ} \mathrm{C}$ for $3 \mathrm{hr}$, and then a drop of the cell-free culture fluid of Erwinia aroideae (AMS 6082) induced by nalidixic acid for $8 \mathrm{hr}$, which was dialyzed against $0.05 \mathrm{M}$ phosphate buffer ( $\mathrm{pH} 7.2$ ), was applied to the plate. After overnight incubation at $30^{\circ} \mathrm{C}$, the formation of a zone of complete growth inhibition in the indicator lawn was examined.

\begin{tabular}{lc}
\hline Bacterial strains & Sensitivity \\
\hline Erwinia carotovora-2 & + \\
E. carotovara-3 & - \\
E. carotovora-6 & - \\
E. carotovora-7 & - \\
E. carotovora IAM & - \\
E. carotovora B21 & - \\
E. carotovora & \\
E. milletiae & - \\
E. aroideae-645Ar & - \\
E. aroideae & (AMS 6082)
\end{tabular}

+ , zone of complete inhibition appeared.

- , zone of inhibition did not appeared.

activity was lost completely by heating at $100^{\circ} \mathrm{C}$ for $10 \mathrm{~min}$. No plaque was formed when the diluted induced culture fluid was spread over the susceptible strains on nutrient agar plates.

This bacteriocin was partially purified by ultracentrifugation, ammonium sulfate fractionation and ion-exchange chromatography on diethylaminoethyl (DEAE)-cellulose. The induced culture fluid of $E r$ winia aroideae, which was prepared by the methods described previously, ${ }^{5)}$ was centrifuged at $105,000 \times$ $g$ for $60 \mathrm{~min}$. Pellets were suspended in $0.05 \mathrm{M}$ phosphate buffer ( $\mathrm{pH}$ 7.2) and solid ammonium sulfate was added slowly with stirring to $15 \%$ saturation. After $30 \mathrm{~min}$, the precipitate was discarded, and the salt concentration of the supernatant was increased to $30 \%$ saturation by further addition of solid ammonium sulfate. The precipitate was collected by centrifugation, dissolved in a minimum volumes of $0.05 \mathrm{M}$ phosphate buffer ( $\mathrm{pH}$ 7.2) and dialyzed against 100 volumes of $0.01 \mathrm{M}$ phosphate buffer ( $\mathrm{pH} 7.2$ ) overnight. The dialyzed material was loaded onto a DEAEcellulose column previously equillibrated with $0.01 \mathrm{M}$ phosphate buffer ( $\mathrm{pH}$ 7.2). After washing with the same buffer, the column was eluted with a linear gradient of sodium chloride from 0 to $0.5 \mathrm{M}$ in $0.01 \mathrm{M}$ 
phosphate buffer ( $\mathrm{pH}$ 7.2). Fractions containing the highest activity were pooled, dialyzed against distilled water and centrifuged at $105,000 \times g$ for $60 \mathrm{~min}$. Pellets having bacteriocin activity were resuspended in distilled water. The suspension was negatively stained with neutral potassium phosphotungstate and examined under an electron microscope (JEM100 B). As shown in Fig. 1, These particles had a

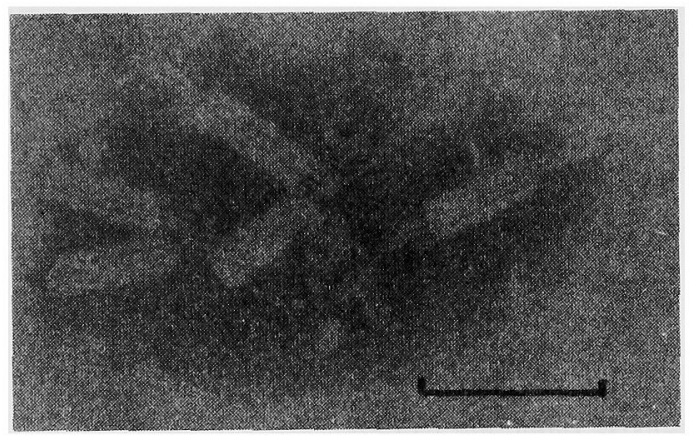

FIG. 1. Electron Micrograph of Bacteriocins.

The original micrograph was taken at the magnification of $\times 60,000$. Scale maker represents $100 \mathrm{~nm}$.

structure similar to that of pyocin $\mathrm{R}$, which resembled to $T$-even phage tails. ${ }^{6)}$ It appears that the particle consists of a contractile sheath with a diameter of $23 \mathrm{~nm}$ and a core with a diameter of $8 \mathrm{~nm}$. Bulk of the material was protein. No detectable DNA was present. Although detectable amount of RNA was present, it might be possibly due to the contamination of ribosomes.

Further purification and characterization of carotovoricin have been recently carried out in our laboratory (Y. Itoh et al. manuscript in preparation).

The authors are grateful to Prof. $\mathbf{H}$. Tsuyama, the Faculty of Agriculture, Iwate University, for the generous supply of Erwinia species used for the test of susceptibilities. We also thank to Mr. T. Sato for his excellent assistance in the operation of the electron microscope. This investigation was supported in part by a grant to H. T. (056023) from the Ministry of Education, Science and Culture.

\section{REFERENCES}

1) Y. Hamon and Y. Péron, Compt. Rend., 253, 913 (1961).

2) Y. Endo, H. Tsuyama and F. Nakatani, Ann. Phytopath. Soc. Jpn., 41, 40 (1975).

3) H. Tomizawa and H. Takahashi, Agric. Biol. Chem., 35, 191 (1971).

4) S. Kamimiya, K. Izaki and H. Takahashi, ibid., 36, 2372 (1972).

5) S. Kamimiya, T. Nishiya, K. Izaki and $\mathbf{H}$. Takahashi, ibid., 38, 1071 (1974).

6) S. Ishii, Y. Nishi and F. Egami, J. Mol. Biol., 13, 428 (1965). 